\title{
Investigation of Pre-service Teachers' Opinions about Science in Terms of the Basic Elements of the Education Program
}

\author{
Ozge Aydin Sengul \\ Correspondence: Ozge Aydin Sengul, Education Faculty, Dumlupinar University, Kutahya, Turkey
}

Received: March 23, 2016 Accepted: April 12, $2016 \quad$ Online Published: April 18, 2016

doi:10.11114/jets.v4i7.1486 URL: http://dx.doi.org/10.11114/jets.v4i7.1486

\begin{abstract}
The purpose of the current study is to investigate the pre-service teachers' opinions about science within the context of the basic elements of the education program, such as objectives, content, learning-teaching process and evaluation. The study was designed as a case study, one of the qualitative research methods. The participants of the study are eight, university fourth-year, pre-service science teachers. In the study, a semi-structured interview form consisting of eight questions was used to collect data. During the data collection process, the questions in the interview form were asked of the participants individually and each interview lasted about 20-29 minutes. The collected data were analyzed through "descriptive analysis" and "content analysis". The findings of the study were systematically tabulated according to the emerging codes and themes and supported with direct quotations from the participants. At the end of the study, it was found that the pre-service teachers could explain the objectives of science. Moreover, the pre-service teachers were found to be evaluating the content of science in terms of scientific disciplines, skills, basic features and current developments; the learning-teaching process in terms of individual differences, materials, methods-techniques and approaches and learning environment and the evaluation process in terms of evaluation time and methods-techniques and approaches.
\end{abstract}

Keywords: science, elements of the education program, pre-service science teachers

\section{Introduction}

Science occupies an important place in people's lives. Therefore, in our education system, there is a course specifically addressing the teaching of sciences and a curriculum was developed for this course (Ayvaci \& Bakirci, 2012). The Elementary School Science and Technology Course Curriculum, put into effect in 2004-2005 and implemented up to the 2013 school year, was then revised as the Sciences Course Curriculum in 2013. The vision of the new program was defined as "Educating all students as science literate individuals" (MEB, 2013). The vision of the program did not change but some new amendments were made in the program (Toraman \& Alci, 2013). The basic elements of an educational program are objectives, content, learning-teaching process and evaluation. Within the dimension of objectives, answers to the question "Why do we educate individuals?" are sought. Within the context of the content dimension, answers to the question "What should be taught?" to achieve the objectives. Within the context of the learning-teaching dimension, answers to the question "How should we teach?" are sought. Within the dimension of evaluation, a check is performed on the quality of the education (Demirel, 2010). Educational programs, and instructional programs designed within the framework of educational programs, can be viewed as guiding maps to plan all the educational activities within and out of the school. Thus, well-prepared educational programs are believed to facilitate the accomplishment of the objectives (Crray, Kucukyilmaz \& Guven, 2015).

Science education given at schools should be established on solid grounds and should be able to meet the needs of the individual and the society (Gurdal, 1992). It is of great importance to impart basic skills, such as knowing and understanding, inquiry and discovery, design and creation, utilization and application, to students in the science courses. The main objective of science education is not to make students recite scientific information but to inculcate attitudes and skills required to solve problems that can be encountered throughout the lives of students and to facilitate students' access to information (Kaptan, 1999). For the attainment of the objectives of science education and for the inculcation of the target skills in students, pre-service teachers should be informed about educational programs and how to conduct learning-teaching and evaluation processes in compliance with the objectives. One of the most important factors affecting the success of educational programs is the teacher. The teachers' information, skills, attitudes and beliefs related to educational programs determine how effectively they will conduct the programs (Aydin \& Boz, 2012). 
While the program put into effect in 2004 was built on a constructivist approach, the basis of the 2013 program lies on a research-inquiry based approach, one of the constructivist learning approaches. It is stated that the new program adopts research-inquiry based learning strategies encouraging students to take responsibility for their own learning and enabling them to construct information in their minds (Kucukyilmaz, 2014). In the program, within the dimension of strategies and methods, the main emphasis is on the creation of learning environments where students can be active and teachers can be guiding and directing. Within the dimension of evaluation and measurement, the main emphasis is on the utilization of complementary evaluation techniques and tools together with the traditional evaluation tools (MEB, 2013). Thus, it can be argued that the success of pre-service teachers in implementing the instructional program is closely associated with their self-efficacy regarding the constructivist approach underlying the basis of the program, teaching methods, evaluation-measurement approaches and in-class behaviors.

Self-efficacy is defined as individuals' beliefs about how they feel, think, motivate and behave (Bandura, 1994). In other words, self-efficacy is the individual's own conception, belief and judgment about his/her capacity and ability to deal with different situations and to accomplish a specific task (Senemoglu, 1997). When the concept of self-efficacy is considered in relation to teachers, it can be viewed as their instructional skills and behaviors demonstrated in the class to facilitate students' task of achieving learning outcomes (Tschannen Moran \& Woolfolk Hoy, 2001; Yaman, Cansungu Koray \& Altuncekic, 2004, Kucukyilmaz \& Duban, 2009). It is stressed that there is a significant relationship between teachers' self-efficacy beliefs and student-teacher communication and student achievement (Ashton, Webb \& Doda, 1983). Teachers having high self-efficacy beliefs tend to use different teaching methods effectively during instructional activities, do research to improve the teaching methods they use and make use of various devices and equipment for their instructional activities (Henson, 2001).

The effectiveness of the implementation of a program is contended to be related to the quality of the training given to pre-service teachers who will be implementers of the program in the future; thus, their self-efficacy regarding science instruction, teaching methods and measurement-evaluation approaches should be nurtured. In general, the relevant literature focuses on pre-service teachers' opinions about the science course program (Cıray, Kuçukyilmaz \& Guven, M., 2015; Toraman \& Alci, 2013; Unisen \& Kaya, 2015; Yildirim \& Gungor Akgun, 2015; Ayvaci \& Ozbek, 2014; Anagun, Kilic, Atalay \& Yasar, 2015; Karatay, Timur \& Timur, 2013), self-efficacy beliefs about science teaching (Bikmaz, 2006; Yaman et al., 2004; Akbas \& Celikkaleli, 2006; Bayraktar, 2011; Saracaloglu \& Yenice, 2009; Karaduman \& Emrahoglu, 2011; Onen \& Muslu Kaygisiz, 2013; Kucukyilmaz \& Duban, 2009); teaching methods (Çimen \& Yilmaz, 2013) and measurement-evaluation approaches (Sasmaz Oren, Ormanci \& Evrekli, 2014). On the other hand, the amount of qualitative research looking at pre-service teachers' opinions about science is quite limited. In this respect, the purpose of the current study is to qualitatively investigate the pre-service teachers' opinions about science in terms of the basic elements of the educational program, such as objectives, content, learning-teaching process and evaluation.

\section{Method}

In the current study, a qualitative research method was employed to determine the pre-service teachers' opinions about science. In this method, the pre-service teachers' opinions about science in terms of the objectives, content, learning-teaching process and evaluation process were investigated to elicit data about these dimensions. The study was designed as a case study. According to Creswell (2007), case study is a qualitative research approach in which researchers examine one or a few cases containing multiple sources within the time limited by the data collection tools (such as observations, interviews, audio-visual, documents, reports), and identify cases and themes depending on the case. This research was conducted by face-to-face interview.

\subsection{Participants}

The participants of this study were selected from among the $4^{\text {th }}$ year pre-service elementary science teachers enrolled in a state university. Eight $4^{\text {th }}$ year pre-service elementary science teachers were randomly selected for the interviews from among the volunteering students. Approximately equal numbers of female and male participants were selected. There are various courses of science and instruction in science teacher education programs. Within these courses, opportunities are provided for pre-service teachers to develop their teaching strategies, classroom management and effective learning strategies. Moreover, they are imparted with positive attitudes towards science and science teaching. In line with the purpose of the current study, the criteria adopted in the selection of the pre-service teacher to take part in the study were their being senior students eligible for graduation and having taken all the courses related to science and science teaching. Instead of their names, codes such as S1, S2, S3 .. S8 were used to identify the participants.

\subsection{Materials}

An "Interview Protocol" was developed to be used for this research. The individual interview protocol consists of 13 semi-structured, open-ended questions designed to obtain responses that pertain to the research questions. Those questions were developed with the help of related literature and the experience of the researchers. While preparing the 
questions, researchers appealed to two authorities for their opinions and then reorganized the questions in light of these opinions.

\subsection{Procedures for Data Collection}

An interview protocol approach was employed in the collection of the research data. In this approach, sticking to the topics or contents determined in advance, the researcher has the freedom of asking both these prepared questions and the extra questions thought to be necessary to elicit important details during the interviews. Interview protocol is a method developed to ensure the coverage of all the dimensions and questions pertinent to the research problem (Yildirim \& Simsek, 2008). In this study, participants' opinions were investigated through interviews. During the interviews, an interview form with open-ended questions was used. The pre-service elementary science teachers were informed about the interview process before the interviews. The questions in the interview form were directed to the participants individually for in-depth elicitation of their opinions and each interview lasted about 20-29 minutes. With the permission of the participants, the interviews were recorded.

\subsection{Procedures for Analysis of Data}

The data collected in the interviews were analyzed through "descriptive analysis" and "content analysis". In the first stage of the data analysis, interview recordings were listened to once. By examining the data obtained, they were divided into meaningful sections and a coding list was formed. During the data coding process, it is necessary for researchers to read the data set several times and work on the emerging codes over and over again (Yildirim \& Simsek, 2008). On the basis of the established list of codes, themes that could explain the data at a general level and subsume the codes under certain categories were determined. The data were systematically described, tabulated and interpreted according to the emerging codes and themes. Moreover, quotations from the students' statements are also presented in relation to the themes.

In qualitative research, reliability often refers to the stability of responses to multiple coders of data sets (Creswell, 2007). To ensure the reliability, the data analysis process was conducted by two independent coders. These coders have studied science education before. All coding was done independently and separately. It was found that the inter-rater reliability value for the data obtained from pre-service elementary science teachers is .92. It is thought that this value is high enough to establish inter-rater reliability.

\section{Results}

In this section, in line with the purposes of the current study, first code and theme lists constructed on the basis of the pre-service teachers' opinions about science and then excerpts of students' responses are presented together with the related theme. The pre-service teachers' opinions were evaluated in relation to the themes of "the objectives of science", "the content of science", "the learning-teaching process in science" and "the evaluation process in science". In Table 1, one can see the list of codes pertinent to the theme of "the objectives of science".

Table 1. The list of codes related to the theme "the objectives of science"

\begin{tabular}{ll}
\hline THEME & CODES \\
\hline \multirow{3}{*}{ Objectives of science } & Explaining natural events \\
& Making sense of the environment \\
& Questioning events \\
\hline
\end{tabular}

The pre-service teachers evaluated "the objectives of science" in terms of explaining natural events, making sense of the environment and questioning events. In this connection, some student excerpts are presented below:

Science means everything in our life.... Science is very important for the explanation of many natural events...We make use of science in many places to find answers to the questions we encounter. Through the information we gain from science, we question the events we encounter (S2).

I think that science entails informing people about nature and the environment and conducting research on them. Moreover, it enables us to understand our environment better (S8).

I think science means an individual's transferring the acquired information into daily life while interacting with nature and the environment (S5).

I think that science can be related to daily life.... For instance, even the reason for a falling apple seen while walking on the road can be explained through science. Science represents a discipline of science through which we can explain natural events; thus, it will always be necessary for students to learn (S1).

In Table 2, one can see the list of codes related to the theme of "the content of science" determined on the basis of the pre-service teachers' opinions. 
Table 2. The list of codes related to the theme of "the content of science"

\begin{tabular}{lll}
\hline THEME & CODES & \\
\hline & & Physics \\
& Scientific Disciplines & Chemistry \\
& & Biology \\
& & Technology \\
\cline { 2 - 2 } The content of science & Scientific process skills \\
\cline { 2 - 3 } & & Thinking skills \\
& & Communication skills \\
& \multirow{3}{*}{ Basic features } & Psycho-motor skills \\
& & Identifying cause and effect relationship \\
& & Relating daily life \\
& Being experimental \\
& & Being process-oriented \\
& Relating numerical data \\
\cline { 2 - 3 } & & Journals \\
& Current developments & Newspaper news \\
& Articles \\
& Internet \\
\hline
\end{tabular}

The pre-service teachers evaluated the theme of "the content of science" in terms of scientific disciplines, intrinsic skills, basic features and current developments. First, the pre-service teachers determined the related science disciplines as physics, chemistry, biology and technology. In this connection, some student excerpts are presented below:

What comes to my mind first, when I hear science, is technology. Science is usually applied through technology, good utilization of technology and technological concepts (S1).

As we know, science is taught within the context of physics, chemistry and biology courses....In elementary school, in more simple forms.... These concepts come to my mind (S6).

What comes to my mind first, when I hear the word "science", is the laboratory. Then the use of physics, chemistry and biology.... For instance, acid-base experiments for the concepts of acid and base, learning by doing and experiencing.... (S7).

The pre-service teachers stated that science includes the scientific process skills, thinking skills, communication skills and psycho-motor skills, and emphasized what should be done to improve these skills. In this connection, some student excerpts are given below:

I would make my students engage in group work to develop their higher level thinking skills. During group work, students consult each other, learn to share and how to communicate their opinions. I could construct discussion environments in my class; thus, their communication skills improve (S1).

In science, scientific process skills are very important. I think scientific process skills can be imparted to students by means of experiments. I would take my students outside. I would ask them to make observations in nature. It would be wonderful. For example, I would introduce some plants to them in biology (S4).

I would want students to conduct inquiries to encourage them to think critically and creatively in the science courses. For instance, I would present them with a problem situation and I would also give the stages of inquiry and then I would expect them to make an inquiry. Students establish hypotheses, collect data and conduct experiments. I would employ a problem-based learning method. I would present them with an experiment and then ask questions, such as what will happen now and what will happen at the end I would want them to make guesses. I would also want them to present the report they have prepared in the classroom so that they could share their opinions with their peers (S3).

I can form discussion groups in the class. While one is supporting one idea, another may support other ideas. I might present an idea and ask them to discuss it on the basis of their prior knowledge. I could enhance their creativity by making them develop suitable materials for this purpose. While developing their materials, I would ask them to find all the required ingredients on their own. Thus, their creativity may increase. For example, a student made a model of organelles with foam (S5).

Experiments can be used for many different purposes. The students may be asked some questions so that they collect some prior information and make some observations. For example, when I was in middle school, there was a bean experiment. The student was given a bean and asked to observe its development. Thus, students can develop their scientific process skills. They observe events, investigate their causes, examine differences and consider the factors affecting the process. Thus, they start constructing the events on their own (S7). 
The pre-service teachers mentioned identifying cause and effect relationships, relating daily life and numerical data and being experimental and process-oriented as the main features of science. In this connection, some student excerpts are given below:

When I hear science, the concepts of science, technology and research come to my mind. I can describe science as a process; as focusing on the process rather than the product; that is, producing something (S8).

For example, in physics you can use many topics, such as force and movement, in your daily life. You can transfer everything you learn in a life science course into daily life. Science education should somehow be related to daily life $(\mathrm{S} 1)$.

When I learn physics, chemistry and biology, my view of life changes. For instance, while I am cooking, I think their pertinence to daily life is greater than other courses' (S7).

Science searches for the causes in life. It investigates the causes and effects of an event and creates connections. It has very close relations with technology (S2).

The pre-service science teachers find the use of some sources, such as journals, newspaper news, articles and the internet, important in terms of making connections between the content of science and current developments. In this connection, some student excerpts are given below:

I try to follow technological developments as much as I can. I read journals. I can give information about technological developments to my students within the context of some courses or I can hand out some related materials (S1).

For example, the Chinese or the Japanese designed a new car that can also be both a helicopter and a plane. This was very interesting to me. I want to share such news with my students... I would recommend them to read journals of science and technology. They might bring them into class and discuss. I would try to increase their curiosity in science (S3).

I would recommend science journals to children. I would bring news related to technological developments to class, and would have them do the same thing. I would spend the last 15 minutes of the class for such activities. I would like them to bring science and technology news they find interesting (S4).

I would try to relate the topic to technological developments. I would look for articles related to the topic I will teach. If I found something to share, I would present it to students by somehow simplifying it for the students to understand. Thus, students could find opportunities to follow the developments taking place in the scientific world. In general, research topics draw the interest of science students. In turn, they themselves initiate some research and follow the developments (S6).

In Table 3, one can see the list of codes related to the theme of "the learning-teaching process in science" determined on the basis of the pre-service teachers' opinions. 
Table 3. The list of codes related to "the learning-teaching process in science"

\begin{tabular}{|c|c|c|c|c|}
\hline THEME & \multicolumn{4}{|l|}{ CODES } \\
\hline & \multicolumn{4}{|l|}{ Individual differences } \\
\hline & \multirow[b]{2}{*}{ Materials } & $\begin{array}{l}\text { Three-dimensional } \\
\text { materials }\end{array}$ & \multicolumn{2}{|l|}{ Models } \\
\hline & & Technologic materials & \multicolumn{2}{|l|}{$\begin{array}{l}\text { Video } \\
\text { Microscope } \\
\text { Computer } \\
\text { Tablet } \\
\text { Projector } \\
\text { Overhead projector } \\
\text { Animations } \\
\end{array}$} \\
\hline & $\begin{array}{l}\text { Methods-techniques and } \\
\text { approaches }\end{array}$ & \multicolumn{3}{|l|}{$\begin{array}{l}\text { Discovery learning } \\
\text { Expository teaching } \\
\text { Question-answer technique } \\
\text { Experimental method } \\
\text { Project-based learning } \\
\text { Problem-based learning } \\
\text { Lecturing } \\
\text { Observation method } \\
\text { Discussion method } \\
\text { Case study method } \\
\text { 5E model } \\
\text { Inquiry approach } \\
\text { Analogy method } \\
\text { Brain storming technique }\end{array}$} \\
\hline \multirow[t]{7}{*}{$\begin{array}{l}\text { Learning-teaching } \\
\text { process in sciences }\end{array}$} & \multirow{7}{*}{ Learning environment } & Physical arrangement & $\begin{array}{l}\text { Seating arrangement } \\
\text { Cleaning } \\
\text { Ventilation of the class } \\
\text { Use of colors }\end{array}$ & \\
\hline & & Rules & $\begin{array}{l}\text { Keeping silent } \\
\text { Talking with permission } \\
\text { Not talking with their p } \\
\text { Being respectful of othe } \\
\text { Active participation in } 1\end{array}$ & $\begin{array}{l}\text { ers } \\
\text { s'opinions } \\
\text { sson } \\
\end{array}$ \\
\hline & & \multirow{3}{*}{ Communication } & $\begin{array}{l}\text { Student-student } \\
\text { communication }\end{array}$ & $\begin{array}{l}\text { Group works } \\
\text { Activities } \\
\text { Formation of } \\
\text { homogenous groups }\end{array}$ \\
\hline & & & $\begin{array}{l}\text { Teacher-student } \\
\text { communication }\end{array}$ & $\begin{array}{l}\text { Democratic } \\
\text { approach }\end{array}$ \\
\hline & & & $\begin{array}{l}\text { Teacher-parent } \\
\text { communication }\end{array}$ & $\begin{array}{l}\text { Informing about } \\
\text { their children } \\
\text { Understand interest } \\
\text { in their children }\end{array}$ \\
\hline & & \multirow[b]{2}{*}{ Behaviors } & $\begin{array}{l}\text { Response to desired } \\
\text { behaviors }\end{array}$ & $\begin{array}{l}\text { Rewarding } \\
\text { Reinforcing } \\
\begin{array}{l}\text { Assigning extra } \\
\text { grades }\end{array} \\
\end{array}$ \\
\hline & & & $\begin{array}{l}\text { Response to } \\
\text { undesired behaviors }\end{array}$ & $\begin{array}{l}\text { Warning with the } \\
\text { eye } \\
\text { Verbal warning } \\
\text { Seeking help from } \\
\text { family } \\
\text { Referring to } \\
\text { counseling service } \\
\text { Giving } \\
\text { responsibility }\end{array}$ \\
\hline
\end{tabular}

The pre-service teachers evaluated the theme of "the learning-teaching process in science" in terms of individual differences, materials, methods-techniques and approaches and learning environment. The pre-service teachers emphasized the importance of individual differences as follows: "individual differences are very important to me (S8)." "I would take children's readiness level and individual differences into consideration (S2)."

The pre-service teachers defined the materials used in the learning-teaching process as three-dimensional materials and technologic materials, and while three dimensional materials include models, technologic materials include computers, 
tablets, projectors, overhead projectors, videos, animations and microscopes. In this connection, some student excerpts are given below:

For example, while teaching the concepts of the digestive system, I can make use of three-dimensional materials. I can use models. In this way, I could raise the curiosity of students and thus their interest in the lesson would increase (S1).

While conducting experiments, for instance, we use a microscope. We can also use different animations in the lesson. There are many different animations that can be used in science classes. In order to make effective use of these materials, I need to have a good command of technology (S1).

I would use a computer and projector in my classes.... I would use microscopes in the laboratory.... Students are now closely engaged in technology. They have computers in their homes. They can easily conduct investigations on the internet (S2).

I could bring a model of the human body into the class as a material .... While teaching the human body, I would certainly bring a model to draw the attention of the students. It would arouse the curiosity of students. When they saw this material, they might wonder what would happen. If I couldn't find such a visual material, then I could show visual materials from the internet (S3).

I would use materials for the topic of systems or would ask students to create them. First, I would teach the subject and then I would ask them to produce related materials in the class. If they couldn't complete it in the class, then I would assign it as homework (S5).

What is important is not giving ready-made materials to students in the class or in the laboratory, but encouraging them to create their own materials. For example, the topic of organelles in biology can be taught by using play dough, pasta, etc. that are easily available (S8).

The pre-service teachers described the methods-techniques and approaches that can be used during the learning-teaching process as teaching through presentation and discovery, question-answer and brain-storming techniques, project-based and problem-based learning, inquiry approach, experimental and observation method, lecturing, discussions, case study, 5E model and analogy method. In this connection, some student excerpts are given below:

While teaching the concepts of science to students, I would use the analogy method. For instance, while teaching the concepts related to veins and the circulatory system, I could make use of the analogy of streets.... While teaching the concepts related to the cell, I would ask my students to think of a big school, and its principal as the nucleus of it. I could use such analogies (S3).

The methods and techniques I would use in my classes might vary depending on the subject to be taught.... We should use visuals to teach some subjects, while using the expository method, slides and documentaries for others. We could present it as a crude theory.... We may take them on field trips and they might make observations there (S2).

The methods and techniques I would use differ from subject to subject. For example, while teaching the subject of planets, I would prefer to use the lecture method. However, while teaching some topics, such as force and movement, you should conduct experiments. In such cases, you could use teaching through the discovery method. As I said, it depends on the topic you would teach. I would prefer to use the discovery-based experimental method to the greatest extent $(\mathrm{S} 3)$.

I would use the 5E model. I would start the lesson with questions to draw the attention of the students. Therefore, I would use the question-answer method. Project-based learning might also be used. I like working on materials. I believe that students learn better when materials are used. I would also use the discovery method (S5).

I would like to use the brain-storming technique.... I would also try to create an environment where each student could express himself/herself.... Knowing the thoughts of student can help me to guide them (S2).

For example, I would teach according to 5E rules. In the warm-up section, I would ask questions from daily life. I could start by asking questions while teaching a concept instead of giving its definition. Thus, we could reach the definition of the concept by means of questions. Students would give their answers and, with the help of the teacher, they could come up with the definition of the concept. Then, as a teacher, I would offer my explanations about the concept. For example, how can we digest the bread we eat? What happens during this process of digestion? Through such questions, students might gain a better understating of the concept of digestion (S1).

I would present students with a problem statement and then ask them to establish hypotheses. I could divide them into groups and would like them to determine a problem statement, generate hypotheses, collect data and make 
observations. I would like them to conduct research (S2).

I would frequently use case studies for them to follow news and be more sensitive (S8).

The pre-service teachers evaluated the learning environment in the learning-teaching process in terms of physical arrangement, rules, communication and behaviors. Within the physical arrangement dimension, seating arrangement, cleaning, ventilation of the class and the use of colors were mentioned. In this connection, some student excerpts are given below:

I would warn students about keeping the class clean, not throwing rubbish on the floor. I would ventilate the class by keeping the windows open $(\mathrm{S} 1)$.

When I would like to use visual materials, I would arrange the student desks in a U-shape. I might arrange the class depending on the subject to be taught. If I taught something theoretical, then the arrangement should be normal. I would seat the more energetic and active students in the front (S2).

A light and clean class positively affects learning. I would ventilate classrooms as much as possible, so students would feel more active (S6).

The pre-service teachers stated that they would set classroom rules, such as keeping silent in the class, talking with permission, not talking with their peers, being respectful of others' opinions and active participation in the class. In this connection, some student excerpts are given below:

While teaching, I want my students to keep silent and participate in the lesson when necessary. For example, you ask a question, and when the student cannot answer or gives a wrong answer, you immediately give the correct answer. This will have a negative impact on the self-confidence of the student. I would not do this (S2).

There must be rules in the class. These rules should be explained at the beginning by the teacher so that students know and obey them. I would not impose very strict rules. For example, I could lay down a rule for noise: "While I am talking, you will not talk." Of course I would explain this rule with positive statements (S3).

I would set some rules in the class. At first, I would try to appear to be strict. For example, I would say, "Do not talk without permission" (S5).

I would absolutely lay down some rules in the class. Lack of rules makes learning more difficult. There are some well-known rules among students, such as raising hand to talk, not talking between them, not interrupting while another is talking, respecting different opinions.... These are, I think, the basic rules and they must be enforced (S6).

The pre-service teachers evaluated the communication in learning environments involved in the learning-teaching process in terms of student-student communication, teacher-student communication and teacher-parent communication. Within the context of student-student communication, they emphasized the importance of group work, activities and formation of homogenous groups. They defined teacher-student communication on the basis of the characteristics of a democratic approach. Related to teacher-parent communication, they stated that it is necessary to inform parents about their children and understand their interest in their children. In this connection, some student excerpts are given below:

First of all, students should feel happy in the class. I would like them to select where they want to sit, then they would feel more comfortable. I would pay attention to their communication with their peers. I would get tall students seated at the back desks. They could see the board easily (S1).

I would never use punishments. I would like to establish my authority but I would not like to be a very strict teacher. I would like to have good communication with my students so that they could comfortably express themselves. I would not like to lay down rigid rules $(\mathrm{S} 2)$.

I would like to talk to parents frequently. I think parents are very important for children. "Are they interested in their children at home?" I would like to know this. Some parents are too oppressive and some are indifferent. I would like to talk to parents and inform them about their children (S2).

There should be some certain lines between the teacher and the student. We need to inspire trust in the student. I would only talk to parents about their children, would not be very close with them. I could organize some activities to improve students' communication and interaction with each other and conduct group work for them to get to know each other better (S3).

We should not be so close to students. There must be some distance to be kept. On the other hand, during breaks, they could come and ask questions without any hesitation. Therefore, I should treat them a bit leniently. We should be able to keep our relations at a formal level (S5).

We should not be very close to our students. There should be certain borders. They should be aware that we are 
teachers and they are students. In this way, a more effective learning environment could be established. I would try to be in contact with parents as much as I could because we should follow the performance of their children together. If I regularly communicate with parents, I can learn the problems without delay and solve the problem in cooperation with parents (S6).

My only rule seems to be lawlessness. I do not want rules because what is forbidden is more attractive for children. I do not want rules but, of course, this would not adversely affect student learning (S8).

The pre-service teachers evaluated the behaviors in the learning environment in terms of responses given to desired and undesired behaviors. They stated that the responses that could be given to desired behaviors are rewarding, reinforcing and assigning extra grades to students. According to the pre-service teachers, responses that could be given to undesired behaviors are warning with the eye, verbal warning, seeking help from family, referring to counseling service and giving them responsibility. In this connection, some student excerpts are given below:

I would not directly tell off the misbehaving child. I would let him/her see his/her mistakes. I would politely warn him verbally, or I might warn all the class and expect the target student to understand. If he/she would not, I would individually talk to him/her without hurting his/her feelings. When desired behaviors are displayed, I can use reinforcement. I might praise the student by using such expressions as well done, congratulations, etc. I might give small presents such as chocolate or sweets to increase students' motivation. I might promise to give a certain present to students getting high grades $(\mathrm{S} 2)$.

When a desired behavior is encountered, I might reward the behavior with small presents or praise. I think rewarding is motivating for students. I might give chocolate. I might give books as presents to those getting high scores from exams. When an undesired behavior is encountered, for example, there is a student in the class where we go for our teaching practicum course who is very active and talkative. In such a case, I would talk to him/her outside the class. I might seek help from a school counselor. I might assign him/her some tasks such as cleaning the board (S5).

When the rules I set are obeyed, I feel content. I verbally express my contentment. When treated in this way, other students might feel motivated to obey the rules. I would not only reward with praise, I could also reward students with higher grades. When I encounter a negative behavior, I first warn with my eyes. If the undesired behavior persists, I verbally warn him. If it still persists, then I call the family. By following some certain stages, I try to not to hurt the student. I can also talk to the school counselor (S6).

When an undesired behavior is exhibited, I would first ask the reason for it and try to make the student realize his/her misconduct and thus I would help him/her set his/her own rule. If a student talks without first raising his/her hand, I tell him/her, "I cannot hear you", because your friends are also talking. Thus students may start questioning themselves and realize that they cannot hear (S8).

In Table 4, one can see the list of codes related to "the evaluation process in science" determined on the basis of the pre-service teachers' opinions.

Table 4. The list of codes related to the theme of "the evaluation process in science"

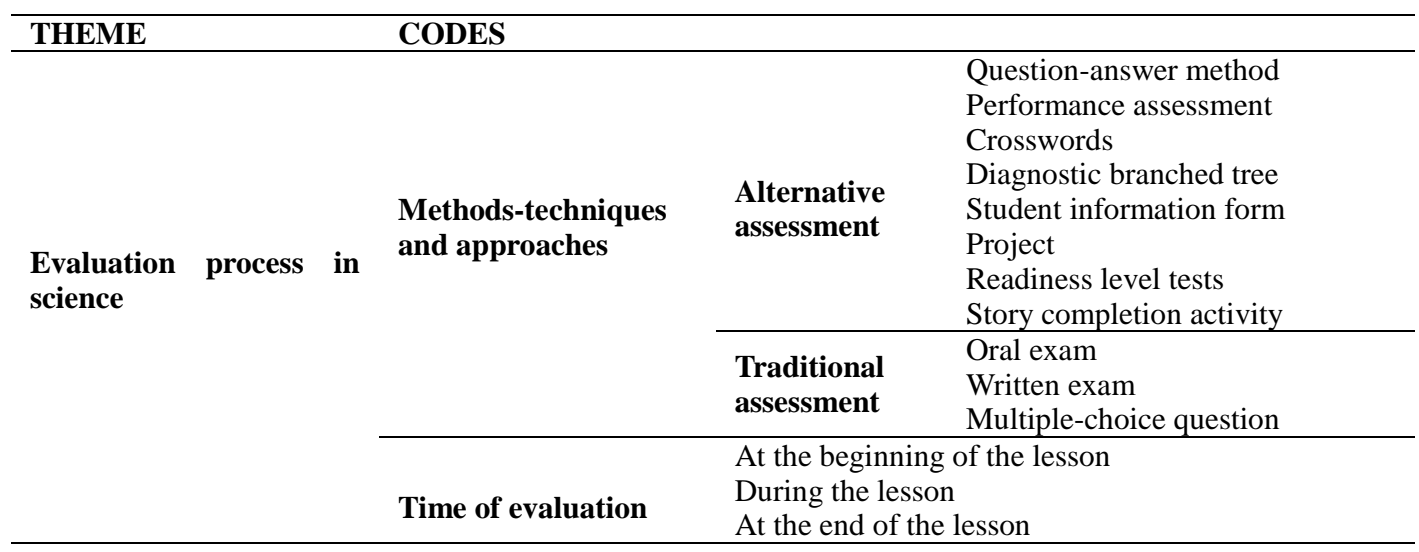

The pre-service teachers evaluated the theme of "the evaluation process in science" in terms of methods-techniques and approaches and time of evaluation. While they expressed the methods-techniques and approaches as alternative assessment and traditional assessment approaches, they included question-answer method, performance assessment, crosswords, diagnostic branched tree, student information form, project, readiness level tests and story completion activities within the alternative evaluation approach. They included oral exams, written exams and multiple-choice 
questions within the traditional evaluation approach. In this connection, some student excerpts are presented below:

For the evaluation, asking questions within the classroom environment is of great importance. The evaluation should not be only based on written exams because, during a written exam, students may not feel good psychologically. During classes, I would ask questions and take some notes and use them for the end-of-the term evaluation. That is, in evaluating students, their classroom performance should be taken into consideration. I think that performance assignments are usually done by parents. Thus, I am not much in favor of them (S1).

Some students experience exam anxiety...they can panic. I would absolutely evaluate my students not only on the basis of written exams but also on their classroom performance. The performance of students during the term should be considered. Crosswords should be used...then they can be solved as a whole class. I could use stories (S2).

It is of great importance for me to put students into the center. Students' readiness level should be considered. Students' abilities are of great importance. Students' awareness of their abilities and talents should be raised (S2).

I would conduct my evaluation primarily at the end of each unit in the form of oral exams, questions and answers. I would not assign many projects to my students, because they are mostly done by parents. The projects might be assigned in such a way as to be performed in the class. They could be done as group work in a specific part of the class. I would use diagnostic trees. I want to evaluate my students during the process (S4).

If I evaluated their knowledge level, then I would use tests. For instance, I would give end-of-unit tests. There should be general exams. By means of general evaluations, we could get to know students better. I also would like to have their personal information (S5).

The pre-service teachers stated that it would be suitable to evaluate students at the beginning of the lesson, during the lesson and at the end of the lesson. In this connection, some students' excerpts are as follows: "I would like them to conduct some activities so that students could discover. At the end of the class, I would ask questions. In fact, evaluation at the beginning, during and at the end of the lesson would be more fruitful. I could detect the shortcomings at the beginning of the lesson, the progress during the lesson, and whether they have gained something at the end of the lesson (S7).

\section{Discussion}

In the current study, the purpose was to determine the pre-service science teachers' opinions about science. The pre-service teachers evaluated science in terms of the dimensions of "the objectives of science", "the content of science", "the learning-teaching process in science" and "the evaluation process in science". First, opinions about the objectives of science were presented. The pre-service teachers defined the objectives of science as explaining natural events, making sense of the environment and questioning the events. The objectives of science are defined in the literature as observing and investigating nature and natural events in a systematic manner, predicting or making guesses about unobserved events, testing whether their guesses are correct or not, trying to understand nature and the relationships between man and nature and finding solutions to the problems encountered (Kaptan; 1999; Soylu, 2004; Cepni, 2006; MEB, 2013). Thus, it can be argued that the pre-service teachers correctly defined the objectives of science.

The pre-service teachers addressed the content of science in terms of its related scientific disciplines, skills involved, basic characteristics and relationships with current development. They identified the scientific disciplines related to science as physics, chemistry, biology and technology. Sciences cover all the scientific disciplines made up of knowledge gained as a result of man's observing his/her natural environment and himself/herself (Cilenti, 1985). The basic disciplines defined to be related to science in the 2013 science course program are biology, physics, chemistry, astronomy, earth and environmental sciences, health and natural disasters. Moreover, in science teacher education programs, there are astronomy, earth and environmental sciences courses as well as physics, chemistry and biology courses (YOK, 2007). Thus, it can be contended that the pre-service teachers' opinions about the scientific disciplines related to sciences are inadequate.

The pre-service teachers stated that the content of science involves scientific process skills, thinking skills, communication skills and psycho-motor skills. Furthermore, they mentioned what should be done to improve these skills. The skills to be imparted to students are classified by the Sciences Course Program (2013) as scientific process skills and life skills. While scientific process skills include making observations, measuring, classifying, recording data, forming hypothesis, using data and constructing models, changing and checking variables and conducting experiments, life skills include analytic thinking, decision-making, creativity, entrepreneurship, communication and team work. In light of these findings, it can be maintained that the pre-service teachers mostly focused on scientific process skills, communication skills and thinking skills in general out of the skills involved in the content of science. 
The pre-service teachers expressed some basic characteristics of science as forming cause and effect relationships, being pertinent to numerical data, being experimental and process-oriented. Costu, Unal and Ayas, (2007) investigated the relationships between the concepts of science and events in daily life and reported that discussion groups and enhanced instruction are more effective in teaching of science subjects. In the current study, it was also found that the pre-service teachers are aware of the importance of relating sciences to daily life. This is a promising finding because it indicates that, when they become teachers, they might emphasize these relationships. The pre-service teachers also emphasized the importance of creating connections between science and current developments. For this purpose, journals, newspaper news, articles and the internet could be useful.

The pre-service teachers emphasized the importance of individual differences in the learning-teaching process, mentioned materials, methods-techniques and approaches to be used in this process and evaluated the learning environment. Organization of educational-instructional activities by teachers considering individual differences in terms of learning process enables students to attain better outcomes and facilitates the teacher's job from many respects, particularly in relation to the task of classroom management (Kurt \& Ekici, 2013). In this regard, the pre-service teachers' attaching importance to individual differences is a positive finding of the current study because this may show that they will arrange their future instruction considering individual differences. For the construction of an effective learning environment in science, use of various methods, techniques and approaches and visual materials to support the instruction is of great importance. The pre-service teachers stated that materials such as models, computers, tablets, projectors, over-head projectors, videos, animations and microscopes could be used in the learning and teaching process. The pre-service teachers also stated that various methods, techniques and approaches such as learning through presentation and discovery, question-answer and brain-storming technique, project-based and problem-based learning, research-inquiry approach, experimental method, lecturing, field trip and observation, discussion method, case study method, 5E model and analogy method could be employed. Kucukahmet (2005) defined student-centered methods and techniques as role play, field trip, projects, discussions and problem solving and teacher-centered methods and techniques as presentation and question-and-answer method. Antoniadou and Skoumios (2013) investigated the opinions of teachers about science learning and teaching and found that the teachers mostly use methods and techniques such as cognitive conflict, brainstorming, questions, debate, concept maps and the experiment, while very few of them also use methods and techniques such as exploration, questions, discussion and experiment. Gurbuz, Toman, Aksoy and Odabas1 Cimer (2013) reported that the pre-service teachers generally prefer recitation and discussion methods from among the existing instructional methods and techniques. Some of the methods to be used in learning environments are defined by the sciences course program (2013) as problem-based learning, project-based learning, argumentation, inquiry-based learning and cooperative learning. In addition, for the information gained from the course of science to be meaningful and permanent, learning should not only occur within the school, but also out-of-school learning environments should be capitalized on (Cavas \& Huyuguzel Cavas, 2014). When the opinions of the pre-service teachers were evaluated, it was found that although they mentioned many methods and techniques used in teaching of sciences, they did not mention other methods and techniques, such as concept maps, multiple-intelligence theory and argumentation. This is expressed by one of the pre-service teachers as follows: "If I knew other methods and techniques, I would also like to use them, but I do not know. I need to do some research (S4)". Thus, it seems to be clear that pre-service teachers should be given more information about the existing techniques, methods and approaches and they should be encouraged to use as many of them as possible in the learning environment.

The pre-service teachers evaluated the learning environment in the learning-teaching process in terms of physical arrangement, rules, communication and behaviors. Within the physical arrangement dimension, they pointed out the importance of seating arrangement, cleanliness, ventilation of the classroom and use of colors. Proper arrangement of the class or the physical environment of the class has positive influences on the child's social, emotional, physical and academic development. For students to develop positive attitudes towards school, there should be visual stimulators, good organization, enough space for movement and a secure and loving environment. The teacher should be engaged in planned action to organize this environment as effectively as possible (Akyol, 2006). The pre-service teachers stated that they would lay down classroom rules for students to obey, such as keeping silent in the class, raising hand to get permission to say something, respecting different opinions and active participation in the class. The most effective precaution to prevent undesired behaviors in the class is setting some rules. Students need and want rules. Moreover, they want to know what is expected of them (Tertemiz, 2006). In this regard, the pre-service teachers' awareness of the importance of determining physical order and rules in the class seems to be a promising finding of the current study.

The pre-service teachers emphasized the importance of student-student, teacher-student and teacher-parent communication in the learning and teaching process. They stated that group work, activities and construction of homogenous groups are important in terms of student-student communication. Antoniadou and Skoumios (2013) found that most teachers prefer project group work in which each student conducts project work in their classroom 
organization. Some of them prefer their students to work in cooperation with each other and few of them prefer their students to work individually. The classroom environment, where educational and instructional activities are conducted and a great amount of instructional time is spent, is at the same time a place where student-teacher communication and interaction take place intensively (Ok, Gode \& Alkan, 2000). The pre-service teachers emphasized that the role of the teacher in this process should be democratic. Dreikurs (1982) defined the characteristics of a democratic teacher as follows: he/she greets student on entering the class, wants everybody to sit and waits until drawing the attention of every student, sends signals to students walking at the back of the class indicating that he/she sees them and considers students' opinions while determining the rules to be obeyed in the class (cited by Pala, 2005). In the current study, it is seen that the pre-service teachers stated opinions similar to the ones defined by Dreikurs. The pre-service teachers stated that teacher-parent communication is necessary to inform parents about their children and evaluate their interest in their children.

The pre-service teachers evaluated the behaviors in the learning environment in terms of responses given to desired and undesired behaviors. They expressed the responses to be given to desired behaviors as rewarding students, reinforcing and giving extra points to students. The students obeying the classroom rules and exhibiting desired student behaviors need to be rewarded in different manners. The rewards given to students contribute to the satisfaction of students and proper functioning of the rules. In addition to giving extra grades, the teacher can also give different rewards depending on the student's participation and performance (Tertemiz, 2006). In the current study, it became apparent that the pre-service teachers would use these tactics to reinforce desired behaviors. The responses to be given to undesired behaviors according to the pre-service teachers can be warning with the eye, verbal warning, seeking help from the family, referring to counseling service and assigning responsibility. Tertemiz (2006) stated that after the determination of the rules to be obeyed in the class, the sanctions to be imposed in case of rule violation should be carefully considered. In case of rule violation, the following gradual process is recommended: first, the name of the student is written on the board. In case of a second violation, the student is deprived of his/her right to eat lunch. In case of a third violation, the teacher gives some advice. In case of a fourth violation, the student is referred to the principal school director. In case of the fifth violation, parents are contacted and they are asked to talk to their child. When the pre-service teachers' opinions about undesired behaviors were examined, it was seen that they are also in favor of such a gradual process.

The pre-service teachers stated that it would be suitable to evaluate students at the beginning of the lesson, during the lesson and at the end of the lesson. They divided the methods-techniques and approaches to be adopted in this process into two, as alternative evaluation and traditional evaluation approaches. According to the pre-service teachers, while alternative approaches can include question-answer method, performance evaluation, crosswords, diagnostic tree, student information form, project evaluation, readiness level tests and story completion activities, traditional approaches can include oral and written exams and multiple-choice questions. With the changes made in educational programs since 2005, a constructivist approach has been adopted and thus the importance attached to process evaluation has increased. Parallel to the changes made in the educational programs, the need for the adoption of alternative measurement-evaluation approaches has become clear (Sasmaz Oren, 2016; Ozsevgec, 2008; Nartgun, 2006, Cepni and Ayvaci, 2006). In the literature, the techniques and methods constituting alternative measurement and evaluation approach are identified to be performance evaluation, portfolio, concept maps, concept cartoons, semantic analysis table, structured grid, diagnostic tree, guessing-observation-explaining, rubric, journal, word association, project, drama, interview, observation, written reports, demonstration, poster, group, peer and self-evaluation, check list, oral presentation, vee diagram, crossword, information-demand learning card, comment cards, scientific story and tale maps, flash cards and attitude scales (Vurkaya, 2010; Izgi, 2007; Sasmaz-Oren and Ormanci, 2011). In various research, it was determined that pre-service teachers' levels of recognition and utilization of these approaches were low (Usta, Cigir Dikyol and Ince, 2010; Ogan Bekiroglu, 2009; Saglam Arslan, Avci and Iyibil, 2008). In the current study, when the pre-service teachers' opinions about measurement and evaluation approaches were examined, it was found that they expressed a limited number of approaches and they did not have enough information about these approaches. One of the pre-service teachers expressed this situation as follows: "I cannot make any comments as I do not know much about alternative evaluation techniques, but if I knew, I would like to try (S5)". The pre-service teachers should be better instructed about alternative evaluation methods so that they could better use them in their classes.

As a conclusion, in light of the findings of the current study, it can be argued that the pre-service teachers evaluated science in terms of their objectives, content, learning-teaching process and evaluation process and explained the objectives of science. The pre-service teachers evaluated the content of science in terms of scientific disciplines, skills, basic characteristics and current developments; the learning-teaching process in terms of individual differences, materials, methods-techniques and approaches and learning environment; the evaluation process in terms of the time of evaluation and methods-techniques and approaches. In general, it can be maintained that the pre-service teachers could 
not present enough explanations about scientific disciplines, skills and methods-techniques and approaches that can be used in the learning-teaching process and evaluation process. On the basis of these findings of the study, it can be suggested that more importance should be attached to the teaching of methods-techniques and approaches that can be used in the learning-teaching process and evaluation process within the curriculums of science teacher training programs. Moreover, given that it is likely that the opinions stated by the pre-service teachers will find reflection in their classroom when they become teachers, similar studies should be supported with observations. The pre-service teachers' future classroom practices can be evaluated in terms of the dimensions addressed in the current study and thus the extent to which they transfer their opinions into practice can be seen.

\section{References}

Akbas, A., \& Celikkaleli, O. (2006). The investigation of the preservice elementary teachers' science instruction self-efficacy beliefs according to their gender, type of education, and universities. Mersin University Journal of the Faculty of Education, 2(1), 98-110.

Akyol, H. (2006). Olumlu öğrenmeye uygun bir ortam oluşturma. In L. Kucukahmet (Ed.), Sinıf yönetimi (pp.243-264). Ankara: Nobel Yayın Dağıtım.

Anagun, S. S., Kilic, Z., Atalay, N., \& Yasar, S. (2015). Are classroom teacher candidates ready to perform science curriculum? Electronic Turkish Studies: International Periodical for the Languages, Literature and History of Turkish or Turkic, 10(11), 127-148.

Antoniadou, P., \& Skoumios, M. (2013). Primary teachers' conceptions about science teaching and learning. The International Journal of Science in Society, 4, 69-82.

Ashton, P. T., Webb, R. B., \& Doda, N. (1983). A study of teachers' sense of efficacy. Final report, executive summary. Gainesville: University of Florida, Foundations for Education.

Aydin, S., \& Boz, Y. (2012). Review of studies related to pedagogical content knowledge in the context of science teacher education: Turkish case. Educational Sciences: Theory \& Practice, 12(1), 479-505.

Ayvaci, H. S., \& Ozbek, D. (2014), Fen bilimleri dersi 2013 öğretim programına yönelik öğretmen görüşleri (Ordu ili örnegi). Milli Eğitim Dergisi, 204, 214-231.

Ayvaci, H. S., \& Bakirci, H. (2012). Fen ve teknoloji öğretmenlerinin fen öğretim süreçleriyle ilgili görüşlerinin 5E modeli açısından incelenmesi. Journal of Turkish Science Education, 9(2), 132-151.

Bandura, A. (1994). Self-efficacy. In V. S. Ramachaudran (Ed.), Encyclopedia of human behavior (Vol. 4, pp. 71-81). New York: Academic Press. (Reprinted in H. Friedman [Ed.], Encyclopedia of mental health. San Diego: Academic Press, 1998).

Bayraktar, S. (2011). Turkish preservice primary school teachers' science teaching efficacy beliefs and attitudes toward science: the effect of a primary teacher education program. School Science and Mathematics, 111(3), 83-92. http://dx.doi.org/10.1111/j.1949-8594.2010.00065.x

Bikmaz, F. (2006). Elementary school teacher candidates' self-efficacy beliefs and teaching-learning conceptions. Eurasian Journal of Education, 25, 34-44.

Cavas, B., \& Huyuguzel, C. P. (2014). Fen bilimlerinde öğrenme-öğretme süreci. In S. S. Anagun \& N. Duban (Eds.), Fen bilimleri ögretimi (pp.163-192). Ankara: Ani Yayincilik.

Cepni, S. (2006). Bilim, fen, teknoloji kavramlarının eğitim programlarına yansımaları. In S. Cepni (Ed.), Kuramdan uygulamaya fen ve teknoloji ögretimi (pp.1-22). Ankara: Pegem Akademi.

Cepni, S., \& Ayvaci, H. S. (2006). Fen ve teknoloji eğitiminde alternatif (performans) değerlendirme yaklaşımları. In S. Cepni (Ed.), Kuramdan uygulamaya fen ve teknoloji ögretimi (pp.249-264). Ankara: Pegem Akademi.

Cilenti, K. (1985). Fen eğitimi teknolojisi, Ankara: Kadığlu Maatbası.

Cimen, O., \& Yilmaz, M. (2013). An investigation of preservice biology teachers' self- efficacy beliefs regarding the application of teaching methods and techniques. Gazi University Journal of Gazi Educational Faculty 33(1), 51-65.

Ciray, F., Kucukyilmaz, E. A., \& Guven, M. (2015). The views of teachers about the curriculum of science revised for secondary schools. Dicle University Journal of Ziya Gökalp Faculty of Education, 25, 31-56. http://dx.doi.org/10.14582/DUZGEF.566

Costu, B., Unal, S., \& Ayas, A. (2007). The use of daily-life events in science teaching. Journal of Kirsehir Education Faculty,8(1), 197-207. 
Creswell, J. W. (2007). Qualitative inquiry and research design, choosing among five approaches. California: Thousand Oaks.

Demirel, O. (2010). Öğretme sanatı: Öğretim ilke ve yöntemleri. Ankara: Pegem Akademi.

Gurbuz, F., Toman, U., Aksoy, G., \& Odabasi, C. S. (2013). Pre-service science teachers'views about teaching theories and methods. International Journal on New Trends in Education \& Their Implications (Ijonte), 4(4), 197-207.

Gurdal, A. (1992). İlköğretim okullarında fen bilgisinin onemi. Hacettepe Üniversitesi Eğitim Fakültesi Dergisi, 8, 185-188.

Henson, R. K. (2001). Teacher self-efficacy: substantive implications and measurement dilemmas. The Annual Meeting Of The Educational Research Exchange.

Izgi, U. (2007). The effect of alternative assessment attitudes in science lectures on the level of examination anxiety of students and the level of performance of learning (unpublished master dissertation). Hacettepe University, Ankara, Turkey.

Kaptan, F. (1999). Fen bilgisi ögretimi. Istanbul: Milli Eğitim Basımevi.

Karaduman, B., \& Emrahoglu, N. (2011). Sınıf öğretmeni adaylarının bazı değiskenler açısından fen öğretimi öz-yeterlik inanç düzeylerinin ve sonuç beklentilerinin incelenmesi üzerine bir araştırma. Journal of Turkish Science Education, $8(3), 69-79$.

Karatay, R., Timur, S., \& Timur, B. (2013). Comparison of 2005 and 2013 science course curricula. Adiyaman Universitesi Sosyal Bilimler Enstitusu Dergisi, 6(15), 233-264.

Kucukahmet, L. (2005). Öğretimde planlama ve değerlendirme, Ankara: Nobel Yayın Dağıtım.

Kucukyilmaz, E. A. (2014). Fen bilimleri dersi öğretim programı. S. S. Anagun ve N. Duban (Ed.), Fen bilimleri ögretimi (pp.59-86). Ankara: Anı Yayıncılık.

Kucukyilmaz, E. A., \& Duban, N. (2009). Primary teacher candidates' science teaching self-efficacy beliefs and their opinions regarding to the effective factors of self-efficacy beliefs. Education Sciences, 4(1), 71-83.

Kurt, H., \& Ekici, G. (2013). Bireysel farklılıklar ve öğretime yansımaları. In G. Ekici \& M. Guven (Eds.), Öğrenme-ögrretme yaklaşımlarl ve uygulama örnekleri (pp.39-82). Ankara: Pegem Akademi.

MEB (2005). İlköğretim 6, 7 ve 8. Sinf Fen - Teknoloji Dersi Öğretim Programı ve Kılavuzu. Ankara: MEB Yayını.

MEB (2013). İlköğretim Kurumları (İlkokullar ve Ortaokullar) Fen Bilimleri Dersi (3., 4. 5., 6., 7. ve 8. Sinflar) Öğretim Programı. Ankara: MEB Yayını.

Nartgun, Z. (2006). Fen ve teknoloji öğretiminde ölçme ve değerlendirme. In M. Bahar (Ed.), Fen ve teknoloji öğretimi Ankara: Pegem Akademi.

Ogan, B. F. (2009). Assessing assessment: examination of pre-service physics teachers' attitudes towards assessment and factors affecting their attitudes. International Journal of Science Education, 31(1), 1-39. http://dx.doi.org/10.1080/09500690701630448

Ok, M., Gode, O., \& Alkan, V. (2000). İlköğretimde öğretmen öğrenci etkileşimine sınıf yönetimi kurallarının etkisi. Milli Egitim Dergisi, 145, 20-24.

Onen, F., \& Muslu, K. G. (2013). Prospective science teachers' self-efficacy beliefs about teaching science between 6-8 terms and the opinions on these beliefs. Educational Sciences: Theory \& Practice, 13(4), 2449-2453.

Ozsevgec, T. (2008). Egitimde ölçme ve değerlendirme. In O. Taskın (Ed.), Fen ve teknoloji öğretiminde yeni yaklaşımlar (pp.365-419). Ankara: Pegem Akademi.

Pala, A. (2005). Sınfta istenmeyen öğrenci davranışlarını önlemeye dönük disiplin modelleri. Manas Universitesi, Sosyal Bilimler Dergisi, 13, 172-179.

Saglam, A. A., Avci, N., \& Iyibil, U. (2008). Physics prospective teachers' perception levels concerning alternative evaluations methods. Dicle University Journal of Ziya Gökalp Faculty of Education, 11, 115-128.

Saracaloğlu, A. S., \& Yenice, N. (2009). Investigating the self-efficacy beliefs of science and elementary teachers with respect to some variables. Journal of Theory and Practice in Education, 5 (2), 244-260.

Sasmaz, O. F. (2014). Fen bilimlerinde alternatif ölçme değerlendirme. S. S. Anagun ve N. Duban (Ed.), Fen bilimleri ögretimi (pp.277-340). Ankara: Anı Yayıncılık. 
Sasmaz, O. F., \& Ormanci, U. (2011). Teacher candidate levels of familiarity with the methods, techniques and tools composing the alternative assessment approaches. Procedia Social and Behavioral Sciences, 15, 3476-3483. http://dx.doi.org/10.1016/j.sbspro.2011.04.321

Sasmaz, O. F., Ormanci, U., \& Evrekli, E. (2014). The science and technology pre-service teachers' self-efficacy levels and opinions about alternative assessment and evaluation approaches. Educational Sciences: Theory \& Practice, 39(173), 103-117.

Senemoglu, N. (1997). Gelişim öğrenme ve öğretim: Kuramdan uygulamaya. Ankara: Ertem Matbaacılık.

Soylu, H. (2004). Fen öğretiminde yeni yaklaşımlar. Ankara: Nobel Yayın Dağıtım.

Tertemiz, N. (2006). Sınıf yönetimi ve disiplin. In L. Kucukahmet (Ed.), Sinıf yönetimi (pp.67-92). Ankara: Nobel yayın dagitim.

Toraman, S., \& Alci, B. (2013). Fen ve teknoloji öğretmenlerinin yenilenen fen bilimleri dersi öğretim programına ilişkin görüşleri. Ekev Akademi Dergisi, 1(1), 11-22.

Tschannen-Moran, M., \& Woolfolk, H. A. (2001). Teacher efficacy: capturing an elusive construct. Teaching and Teacher Education, 17(7), 783-805. http://dx.doi.org/10.1016/S0742-051X(01)00036-1

Unisen, A., \& Kaya, E. (2015). An investigation into teachers' views on placement of science education in primary $3^{\text {rd }}$ grade. Adlyaman Universitesi Sosyal Bilimler Enstitüsu Dergisi, 8(20), 546-571.

Usta, S., Cigir, D. D., \& Ince, E. (2010). The alternative evaluation tools choosen by social and science teacher candidates. Procedia Social and behavioral Sciences, 2(2), 3457-3462. http://dx.doi.org/10.1016/j.sbspro.2010.03.534

Vurkaya, G. (2010). The effect of using alternative assessment activities on students? success and attitudes in science and technology course (unpublished master dissertation). Kocaeli University, Kocaeli, Turkey.

Yaman, S., Cansungu, K. Ö., \& Altuncekic, A. (2004). Fen bilgisi öğretmen adaylarının öz-yeterlik inanç düzeylerinin incelenmesi üzerine bir araştırma. Türk Egitim Bilimleri Dergisi, 2(3), 355-364.

Yildirim, A., \& Simsek, H. (2008). Sosyal bilimlerde nitel araştırma yöntemleri. Ankara: Seçkin Yayıncılık.

Yildirim, N., \& Gungor, A. O. (2015). Opinions of the third grade classroom teachers about the altered science course. Journal of Kirsehir Education Faculty, 16(2).

YOK (2007). Öğretmen Yetiştirme Lisans Programları, Ankara.

This work is licensed under a Creative Commons Attribution 3.0 License. 